\title{
Ötvösök és kovácsok az Alföld közepe táján
}

\author{
'MADARAS LÁSZLÓ \\ 'Damjanich János Múzeum, 5000 Szolnok, Kossuth tér 4., e-mail: madar@djm.hu
}

MADARAS, L.: Goldsmiths and smiths in the heartland of the Hungarian Plain

Abstract: Discussed here are the burials containing goldsmiths' and smiths' tools from a fairly closed area. Most of these graves have already been published (e.g. by Zsófia Rácz) and are therefore known to the archaeological community. The main focus of this study is whether the craftsmen interred in these graves occupied a specific position in the period's social hierarchy or in their own community.

Keywords: goldsmiths' and smiths' graves; metalworking; craftsmen, community; society

\section{Bevezetés}

Több mint négy évtizede három fiatal régész találkozott. Ma már nem is emlékszem pontosan, hogy milyen alkalomból, de az bizonyos, hogy ez az esemény mindhármunk életében nyomokat hagyott. Bár egyikünk Budapesten, másikunk a Dunántúlon, én pedig az Alföld „,közepén” kezdtem el dolgozni, de a földrajzi távolság ellenére barátok maradtunk. S ami mindvégig összekötött bennünket - ez a szoros szál -, az avarok és a magyarok régészeti kutatásának elhivatott szeretete. Szentpéteri József, Költő László s jómagam mindig is figyeltünk arra, hogy a másik mit csinál, mit ás, mit publikál. Azt persze nem állíthatom, hogy minden kérdés megoldásában egyetértettünk volna, de mindenkor tiszteltük a másik véleményét, álláspontját. S az évek folyamán, ha lehetőségünk adódott, akkor szívesen elbeszélgettünk, újból és újból megvitatva egymás álláspontját, miközben észre sem vettük, hogy egy kicsit talán együtt meg is öregedtünk.

Most éppen Költő László 70. születésnapja ad apropót arra, hogy egy-egy rövid tanulmánnyal tiszteljük meg az ünnepelt Kollegát, jó Barátot.

Tekintettel az alkalomra arra gondoltam, hogy rövid tanulmányommal ne csupán a régész Költő László munkálkodásához kapcsolódjak, hanem emlékeztessek arra is, hogy az Ünnepelt eredetileg a természettudományokhoz kötődött. Első diplomáját a Budapesti Műszaki Egyetemen szerezte, s ezen érdeklődése mindvégig meg is maradt. Sohasem felejtem el, hogy Bóna István Professzor Úr egy eredeti ötletéből kiindulva, megpróbáltuk az öntött griffes-indás övgarnitúrák vegyi összetételét megvizsgálni. Maga a próbálkozás ugyan hamvába holt, de aki a vizsgálatokat elvégezte, az Költő László volt.

Laci barátom érdeklődési körére tekintettel gondoltam azt, hogy a Nagy Magyar Alföld kellős közepén, készítek egy leltárt azon sírok és temetők leletanyagait felhasználva, amelyek valamiféleképpen köthetők a fémmegmunkáláshoz. Ezek lehettek ötvösök és kovácsok egyaránt. Íróasztal mellöl a különbség nehezen dönthető el, főként, ha még azt is figyelembe vesszük, hogy amikor csupán egyetlen szerszám van a sírban, akkor annak jelenléte a halott mellett akár egy „amatőr" barkács mestert is jelenthetett.

Mindezek tudatában szeretnénk néhány síron keresztül érzékeltetni azt, hogy vidékünkön meglehetősen sok olyan temetkezés került elő, melyek az említett mesterségek irányába mutatnak. Adattárunkban előfordulnak olyan sírok, melyeket mindenki jól ismer, azután lesznek olyanok, melyek ugyan már közöltek, de nagy valószínűséggel nem olyan helyen, amelyet sokan látogatnak, s lesznek olyanok is, melyek először lesznek a szakmai közönség elé tárva.

\section{Ötvös- és kovácssírok az Alföld közepe táján \\ 1. Kunszentmárton}

Kezdjük talán a legismertebb, leggyakrabban idézett sírral, a kunszentmártoni ötvössírral. Anélkül, hogy a kisebb könyvtárnyi szakirodalmi hivatkozásokat megismételnénk, csak az alap közleményre, ${ }^{1} \mathrm{~s}$ a legutolsó feldolgozásra ${ }^{2}$ utalunk. Azt szinte meg sem kell említenünk, hogy ezt a sírt sem szakember tárta fel. Viszont óriási szerencsénkre ekkor már Szentesen a múzeum működésének okán (lásd. Csallány Gábor ásatásait és népszerűsítő cikkeit a helyi sajtóban), egy ilyen fontos lelet előkerülése nem maradt visszhang nélkül. Elsődlegesen Pájer Lajos helyi lakos gyűjtötte össze a szétszórt leleteket, majd maga Csallány Gábor hitelesítette a lelőhelyet.

1 CSALLÁNy 1933

2 RÁCZ 2009; RÁCZ 2014. 
Anélkül, hogy részleteznénk az előkerült leletanyagot - hiszen az mindenki által közismert -, néhány temetkezési szokásra ismételten rá kívánjuk irányítani a figyelmet. Mindenekelőtt arra, hogy a sír temetőben került elő és lovassír volt. Majd arra, hogy a teljes páncél sírba tétele plusz a fegyverek (vaskard, lándzsa, nyílcsúcsok, vas tőr) a korai avar kor nehéz páncélos harcosát idézik. Végül, de nem utolsó sorban arra, hogy az ilyen kis létszámú korai avar temetők egész sora került elő Szentes környékén és a Tiszazugban. ${ }^{3}$

\section{Gátér}

Közvetlenül nem tartozik ugyan Jász-Nagykun-Szolnok megyéhez a gátéri temető, de mivel az Alföld középső területén került feltárásra, említése feltétlenül indokoltnak látszik. Ennek a nagy sírszámú temetőnek a közlésében Kada Elek ${ }^{4}$ olyan területeket is említ, melyeken kutatás nem történt, viszont sírok semmisültek meg. A máig példa értékủ megfigyeléseket tartalmazó publikáció-sorozatból a 11. sír leírását idézzük:

„A mély sírban fekvő csontváz bolygatatlan volt ugyan, de mert a víz egészen elborította, nem lehetett a vele eltemetett összes tárgyat megmenteni s elhelyezésüket pontosan megfigyelni. Kétséget kizárólag csak azt lehetett megállapítani, hogy a 2 ezüst függő a fejnél, a szijvégek a has tájékán feküdtek, a jobboldali medenczecsont külső felénél pedig egy csomóban a trébelő magok és vaseszközök. A derék körül sok ezüst lemeztöredék hevert megmenthetetlenül elporladt állapotban. Bronzlemezes szijvég felső trébelt lapja (6. sz.) $60 \mathrm{~mm}$ hosszú és $2 \mathrm{~mm}$ szélességü téglányalakú felső vége lekerekített. Díszítési motívumai e temető egyéb tárgyaitól elütő; a középen lévő keresztalakból, s alatta következő domború díszből keresztény vonatkozásra is lehet talán következtetni. Bronzlemezből préselt félig elkészített szijvég felső lapja (9. sz.); alsó fele paizsalakú, a felső, valamivel magasabb felének oldala 3-3 félkörrel csipkés s két egymást érö körszelettel végződik, a min túl még folytatódik a lemez feldolgozatlan része. A bronzmag, melynél ezt a bronzlemezt kipréselték, a 10. szám alatt. Bronzlemezes, hosszas téglányalakú, hegyes csúcsban végződő szijvég; oldalai rézsút lehajlanak; felülete síma, csupán az alján látszanak vízszintes rovátkok nyomai; az alsó rész közepén szeg. Széles oldalpánttal összekapcsolt ezüstlemezes szíjvég (8. sz.); $70 \mathrm{~mm}$ hosszú és $23 \mathrm{~mm}$ széles téglányalakú, hegyén lekerekített, alját keskeny pánt köti körül, mely felett a lemez közepén egy szeg. Egy pár ezüst függő (12., 13. sz.); a hosszas függőkarika alján 3 egymásba olvadó kis gömb, melyekhez egy nagyobb két félgömbböl álló golyó tartozott. E részek elváltak egymástól; s a 3-as kis gömbcsomó egyiknél hiányzik. Bronzlemezből trébelt, szintén be nem fejezett domború hátú bogárhoz hasonlitó dísz (12. sz.), teste félgömb, felületét középen rovátkolt szalag övezi át, erre keresztben álló ugyanilyen rovátkolt szallagocska háromszögben elhelyezett 3 kis félgömböt csatol a nagyhoz; e nagyobb félgömb szélét gömbsor veszi körül; a fel nem használt lemezrész nincs még lenyírva róla. Lemezes szijvég trébelésére szolgáló bronzmag (3. sz.) $35 \mathrm{~mm}$ hosszú $23 \mathrm{~mm}$ széles téglányalakú, vége lekerekített, szélét gömbsor veszi körül, utána vékony párkánylécz következik; az így övezett mezőt középen kiemelkedö borda szeli ketté, melytöl jobbra és balra 8-as alakban egymásba füződő kettös indadísz vonul. A fentebbihez hasonló, csakhogy jóval rövidebb s inkább csúcsban végződő trébelö mag (4. sz.) díszítése hasonló amazéhoz. Lapos pityke trébelésére szolgáló tömör bronzmag (5. sz.); átméröje $24 \mathrm{~mm}$ széles, gömbök szegélyezik, közepén a kiemelkedő nagyobb félgömböt vékony karikavonal körít; e központi dísz és a szélt képező gömbsor közötti mélyebben fekvő mezöt sugáralakban rövid vonalkák töltik ki. Lemezes bronztárgy trébelésére szolgáló tömör bronzmag (2. sz.) alakja keresztalakban úgy elhelyezett 3 gömbnegyed, hogy egy négyzetalaknak 3 oldalát zárják be; e négyzetalak közepén egy félgömb emelkedik akként, hogy apró gömbsor körít egy kis kördomborulatot; a négyzetalak lefelé, a kereszt szára gyanánt, trapéz alakban folytatódik ferdén lehajló oldalszélekkel s úgy ennek mind a 3 gömbnegyednek domború felülete indafonatokkal díszített. Magassága 46, legnagyobb szélessége 38. vastagsága középen $12 \mathrm{~mm}$. Kúpalakú pitykés gomb trébelésére való tömör mag (1. sz.); a kúp teteje kis gömbszelet, melyböl lefelé irányulólag sugár alakban kis pálczikák vagy vonalak indulnak ki, alattuk összeérő 3-as alakú indafonat, melytöl a kúp aljáig terjedő mezőt csúcsukkal felváltva fel és lefelé helyezett hosszas háromszögek sorozata tölti ki. Átmérője 26, magassága $18 \mathrm{~mm}$. A 9-ik szám alatti rajzon látható, már említett lemezes szíjvég alakítására szolgáló tömör bronzmag (10. sz.) Bronzmag paizsalakú kis szíjvég présélésére (11. sz.); egyik vége csúcsba fut, széle fölfelé haladtan kissé behajlik, simán lemetszett tövénél 3, kissé kidomborodó vízszintes vonal; a lap a középső vonaltól széle felé lejtős. Hossza 25, szélessége $20 \mathrm{~mm}$. Bronz trébelö mag (15. sz.), eredetileg egybeöntött, most ketté törött szárnyalakú részből áll, melynek szélét gyöngysor köríti, a belül maradt kicsiny mezőben inda-dísz. Szélessége $26 \mathrm{~mm}, 130 \mathrm{~mm}$ hosszú, lapos bronzlécecske, mely közepe felé $13 \mathrm{~mm}$-re szélesedik, két vége átlyukasztott korongban végződik; ketté törött s az egyik korong csonka. Bronz pántszalag (16. sz.) két behajtott végén 2 szeg, illetöleg kettö szeglyuk. Hosszúkás bronzlemez-pánt darabja. C alakra hajtott kis felerösítő fül (18. sz.). Valamiféle nyélnek vagy botnak a végére való hengeres bronztok (7. sz.), felső karimája tágasabb, mint az alsó s mindkettőt keskeny párkány köríti, feneke nem egészen zárt; a felső párkány alatt egy megerősítésre szolgáló szeg; a fanyélnek egy darabja még benne van a tokban.

3 Például Kunszentmárton környékén a közelmúltban Kovács Péter tárt fel egy alig négysíros, ám a temetkezési szokásokat tekintve igen érdekes temetőt az M44-es út lelőhelyeinek feltárása alkalmával.

4 Kada Elek 650 sírt tárt fel. 
11. sír b) (rajzok) Vas késpenge, nyélfelöli végén farostok. Hossza 180mm. Két darab hárombordás vas nyílcsúcs. Összerozsdásodott vasdarabok. Vas tüzcsiholó. Hossza 100mm (2. sz.). Lant alakú vascsat töredéke. Vaskarika, átmérője 62mm; egy lapos bronzlemezes gomb s egy másik kettős, kerektestü pitykeféle rozsdásodott bele (3. sz.). Különböző nagyságú vasrudacskák. Vaskalapács vagy csákányféle tárgy (1. sz.), hossza 110mm, mindkét hosszúkás téglaalakú szára a nyéllyuktól szelíden lefelé hajlik, a nyéllyukban fadarab."

Kada Elek ugyan külön szám alatt közli a 11. b sír tárgyait, de azok nagy valószínúséggel a 11. sírban eltemetett mester eszközkészletéhez tartozhattak. Hasonló következtetésre jutott Rácz Zsófia is. ${ }^{5}$ Magyarázatot adni arra, hogy miként is fordulhatott elő ez a kis keveredés, utólag igen nehéz. Azonban nem járhatunk messze az igazságtól akkor, amikor két lehetőséget is felvázolunk. Az egyik maga a feltárás körülményéből eredeztethető, hiszen a mély sírban a feltárás alatt feltört a talajvíz, s mint azt a feltáró megjegyzi: "... a víz egészen elborította, nem lehetett a vele eltemetett összes tárgyat megmenteni, elhelyezésüket pontosan megfigyelni."토 Nem kizárt, hogy a tárgyak kiemelése során történhetett az elszámozás. Egy másik lehetőség a közléssel állhat összefüggésbe. Aki valaha is tárt már fel nagy sírszámú temetőt, az pontosan tudja, hogy az ásatás és a közlés között eltelt idő - még akkor is, ha ez a jelen esetben tiszteletre méltóan rövid volt -, okozhat keveredést. Hiszen ki emlékezhet minden sírra pontosan. Kada kitűnő érzékét mutatja, hogy beiktatta a 11. sír után a 11. b. sír leírását, jelezve ezzel azt, hogy minden bizonnyal ugyanazon sír tárgyairól van szó.

Összefoglalóan leszögezhetjük azt, hogy ez a sír is temetőből, ráadásul egy nagy sírszámú, sokáig használatban lévő temetőből került elő. A mester mellé nem temették el hátasát, noha a közösség gyakorolta a lóval való temetés szokását, s a fegyverarzenálja is csupán néhány nyílvesszőből, esetleg csont lemezekkel nem merevített faíjból állhatott. Mindezen tényekből az a következtetés adódik, hogy a közösség megbecsült, de nem különösebben gazdag tagjáról lehetett szó.

\section{Kisújszállás}

Kisújszállás-Nagykert (1-11. képek) nevű lelőhelyen 2000-ben Csányi Marietta és Tárnoki Judit egy gazdag, korai avar lovassír maradványait mentette meg. A lelőhelyet a helybeli téglagyár agyagbányászatot végző gépsora semmisítette meg, a leleteket Posztós János igazgató gyűjtötte össze, s adta át a kiérkező régészeknek. A tárgyak részletes leírása alól felment bennünket Rácz Zsófia részletes leírása. ${ }^{7}$

Mindenesetre ez a sír is lovassír volt, bizonyíték erre a csikózablája és három kengyele. Arra a kérdésre, hogy magányos sír volt-e vagy egy temető egyik temetkezése, pontos választ nem tudunk adni. Mindkét lehetőség felvetésére lehet analógiát találni. Ráadásul a három kengyel igencsak ritkaság a korszak temetkezéseiben. A halott mellé helyezett vaskard és vas lándzsa azt sugallja, hogy a sírban nyugvó férfi életében - mesterségének űzése mellett - fegyverforgató harcos is volt. Minden kétséget kizáróan a halott mellékletei közé tartoztak a neolit kőeszközök. Ennek ékes bizonyítékai a rajtuk található vas rozsdafoltok. A mester munkavégzéséhez gyakorlati közük aligha lehetett. Mutatja ezt az a tény, hogy a Kárpát-medence egyetlen ötvös- vagy kovácssírjából sem került elő még véletlenül neolit kőeszköz. Minden további találgatás az igazolhatatlan feltételezések világába vezetne bennünket, ezért még csak tippelni sem szándékozunk ebben a kérdésben.

\section{Rákóczifalva}

Rákóczifalva-Kastélydomb„B” sír. A temető sírjaitól kb. 40 méterre a leomló bányafalból került elő egy ötvössír. "Feltehetőleg a már korábban is megbolygatott temetkezés lovassír volt. Mellékletei között Csalog Zsolt lemezes és öntött lószerszám- és övvereteket, kengyelt, zablát, edényt említ. A Damjanich Múzeumban megtalálható tárgyak leírása az alábbi: Tömör öntött bronz préselőminta, amely feltehetőleg lószerszámveretek készítésére szolgált. Középen egy árok osztja ketté. Kettős csepp alakú alsó része felett három vízszintesen elhelyezett borda található (1). Sima szíjvégek készítésére szolgáló öntött bronz préselőminta (2). Félgömb alakú, tömör bronz préselőminta, plasztikus és centrális elhelyezésü rozettadísszel (3). Öntött bronz préselőminta egy félgömb és egy paizs alakú részből összetéve. A félgömbös részem három koncentrikus árkolás, a paizs alakú részen árkolt keret (4). Bronz szalagpánt, elkalapált végein 1-1 szabályos ovális lyuk (5). Két, valószínüleg hurkosfülü vaskengyel (6). Csikózabla (7). Vasszablya (9). Vas fogó (10). Vaskés töredéke (8). Csiholóvas töredéke (11). Ismeretlen rendeltetésű vastöredékek (12). Kissé kihajló peremü tojásdad testü edény, nyakán és hasán beböködött díszítéssel (13)".8

Rákóczifalva területén nem ez az egyetlen avar kori lelőhely. A Vásárhelyi-terv keretében kialakítandó árvíztározó megelőző régészeti feltárása során, a Rákóczifalva-Bagi-föld 8/A lelőhelyen az ELTE Régészeti Tanszékének ásatási területén többek között egy kicsi, aranyember figurát találtak, sajnos szórványként, noha a lelőhelyen egy 250 síros közép- és késő avar temető került elő. ${ }^{9}$

5 RÁCZ 2014, 156-158, és a 19. tábla

6 KadA 1905, 368.

7 RÁCZ 2014, 161-164, és 23-33. t.

8 SelmeCZI - Madaras 1979-80, 146.

9 RÁcz 2012, 409-436, és 2. kép 3.; RÁcz 2014, 80, és 22. abb. 3. 
Ugyanennek a tervnek a keretében a szolnoki Damjanich János Múzeum régészei, Csányi Marietta és Tárnoki Judit egy jelentős telepet kutattak meg. Ez utóbbi közöletlen, a régészeti anyag és a dokumentáció a szolnoki Damjanich János Múzeumban található. Sajnos a három ásatási helyszín egymástól viszonylag távol található, de mindeneképpen alátámasztják a táj viszonylag sűrűn lakottságát.

Azt ennél a leletnél is megállapíthatjuk, hogy az ötvösmester sírja itt is a közösség temetőjéhez köthető. Ámbár az, hogy a sírmező és az ötvös sírja között mintegy 40 méter üres terület volt, bizonyos elkülönülést is jelezhet. A sír itt is lovassír volt, a szablya pedig az új fegyvertípus megjelenését mutatja, s egyben a korszakon belül kronológiai jelentősége is van. Talán figyelmet érdemel az is, hogy a négy verőtő közül kettő olyan tárgyak elkészítésére szolgált, melyek a korai avar anyagban ismeretlenek.

\section{Tiszavárkony}

Tiszavárkony-Hugyinpart lelőhelyen Kaposvári Gyula, majd Cs. Soós Ágnes tárt fel egy 93 síros temetőrészletet. Bennünket az 5. számú sír érdekel. „Ebben egy bolygatott férfi nyugodott hátasával együtt. Tájolása Ény-Dk. A 606. számú sír átvágja, tehát $-60 \mathrm{~cm}$ mélységnél sekélyebb a sírgödör. A bolygatás a koponyát, a bal lapockát és a kulcscsontotérte. Ajobb alkarcsontok a bal felkarcsonthoz lettek behajlitva, a mellen keresztbe, a bal orsó-és singcsontok a bal combcsonton feküdtek. A férfiváz mellékletei: Két lapból álló, kereklezáródású ezüst nagyszijvég. Az eló-és hátlapot egy vékony pántra forrasztották. Az elölap díszítetlen és egy széles lapu kapcsolótag rozsdásodott hozzá, a felső peremet bordázott szalag zárja a medence környékéröl. Rosszezüst nagyszijvég lemezeinek töredékei. Alsó vége kerek lezáródású, felső vége hiányos. Feltehetőleg ezeket a lemezeket is egy keskeny szalagpántra forrasztották, ám ez a pánt megsemmisült, vagy elkallódott. Különböző szélességủ bronzból készült kapcsoló tagok felületükön ólomszerú merevítés maradványaival. Legalább háromféle méretben. Ácskapocs alakú bronzkapcsoló tagok, melyek közül a kisebbek végeire kör alakú lemezeket erösítettek, mégpedig úgy, hogy miután a lemezeket a drótokra ráhúzták, azok végeit elkalapálták. Négy darab ezüst kisszijvég. Alsó végük kereklezáródású, felső peremükön bordázott pánttal. Díszítésük, ha egyáltalán volt, a korrózió miatt nem állapítható meg. Peremük alatt egy nittszeggel. Töredékes ezüst kisszijvégek. Egytagú öntött bronzcsat vas pecekkel. Ovális karikájához paijzs alakú csattest kapcsolódik. Felerősítésére három nittszeg szolgált. A karika és a csattest között egy bemélyítéssel díszítve. Egybeöntött bronzcsat vas csatpecekkel. Karikája ovális, a csattestet két kis szabálytalan négyszög alkotja. Ezeket egy-egy kis bemélyítés választja el a csatkarikától. A négyszögekben található a felerősítésre szolgáló egy-egy bronz szegecs. Kerek karikájú, paizs alakú testü, egybeöntött bronzcsat vas pecekkel. A csatkarikát függöleges bordákkal díszítették. Felerösítésére a csattesten található egy szegecs szolgált. Egybeöntött trapéz alakú bronzcsat felsőhöz kis paizs alakú csattest tartozik. Vas pecekkel. A csattestet két hornyolás tagolja. Díszítetlen. Egybeöntött kerek karikájú áttört hosszúkás testü bronzcsat vas pecekkel. Felerösitésére két kerek fülecske szolgált. Egyélü, egyenes vaskés a tok és a nyél famaradványával. Kovakő. Kétágú lapos villás nyílcsúcs. Háromélü nyílcsúcsok. Vasnyelü kalapács. Gerince a vágóél felé hajlik. Vas sarló töredékei. Kicsiny vas fülecske. A lóváz mellékletei: Két darab hurkosfülü vaskengyel. Vas csikózabla. Préselt félgömb alakú lószerszám díszek ólomszerü merevítő kitöltéssel. Díszítetlenek, már amennyire a töredékekböl meg lehet állapítani. Kereszt alakú rojtos rosszezüst lószerszám veret ólomszerü kitöltéssel."

Tehát egy újabb olyan szerszámmelléklettel eltemetett férfi, akivel hátasát is elföldelték. Fegyvertára igencsak szegényes, mindössze néhány nyílvesszőből és egy feltételezhető ijból állt. Valószínúleg ide kell számolnunk nagyméretű vaskését is. Sírja, a bronz tárgyak számát tekintve a temető egyik leggazdagabbjának számít. Mindemellett csupán három olyan tárgy van, ami egyedi a mellékletei között, ez a sarló és a vas kalapács, illetve egy kis vas fülecske. Ez utóbbi egyértelműen egy faedény tartozéka volt. A vas sarló sírba helyezését magyarázhatjuk kultikus, babonás okokkal is. ${ }^{10}$ Az éles vastárgyak bajelhárító szerepe közismert. Itt emlékeztetnék arra, hogy a kunszentmártoni ötvös sírban nyugvó halott koponyája mögött egy földbe szúrt vaskés volt. Sajnos a sarló síron belüli pontos előkerülési helyét nem ismerjük, de nem zárhatjuk ki annak lehetőségét, hogy ennél a temetkezésnél is ugyanolyan bajelhárító funkciója lehetett, mint az Kunszentmártonban feltételezhető.

A sírból előkerült vasnyelű vaskalapács majdnem egyedi tárgynak bizonyul az avar kori emlékanyagban. Mindösszesen egy analógiáját ismerjük a Kárpát-medencén belül. Ez a tárgy a Kölked-Feketekapu B temető 80. sírjából került elö. ${ }^{11}$ Rácz Zsófia a tiszavárkonyi darab ismeretének híján - hiszen ez mindmáig közöletlen volt - a csákberényi 323. sír vaskalapácsát nevezte meg. ${ }^{12} \mathrm{~A}$ vasnyél alkalmazásának okaként a tárgy súlyának megnövelését adja meg, s skandináv analógiákat hoz fel párhuzamként..13

10 Somogyı 1982, 191-200.

11 Kiss 2001, 25-26, Abb.7. és a II. kötet Taf. 25.10.

12 RÁCZ 2009, 75, és 8. kép 1.; RÁCZ 2014, 149-150, és 145. jegyzet.

13 RÁCZ 2009, 76. 


\section{Karcag}

A Karcag melletti Berekfürdőről, a Béke-100-as major nevű lelőhelyen egy 7-8. századra keltezhető temetőrészlet 27 sírját tártuk fel. A nem különösebben gazdag temetőrészlet 12. sírja vasszerszámokat is tartalmazott.

„A sír leírása: M:-118; Sz.:72-77; H.212; Vh. 165cm. Háton fekvő, nyújtott helyzetü, bolygatatlan férfi váza. A váz bontása közben a sír földjében sok faszénmaradványt figyeltünk meg, a váz medencecsontja erösen hamus volt. Mellékletek: Préselt ezüst lemez (szijvég?) melynek felső pereme hármas bordával tagolt - a bal combcsont felső harmadának külső oldalán a sírgödör falánál. Kettő darab préselt ezüst övveret, a hármas tagolású lencseforma közepén kiemelkedő háromszög - a bal medencelapát felső peremén és a jobb térdkalács belső szegélyén. Benyomott oldalú, téglalap alakú vascsat pecekkel - a gerincoszlop alsó végének jobb oldalán. Trapéz alakú vascsat pecekkel - a jobb alkarcsontok felső harmadának belső oldalán. Egyélü, egyenes vaskés a tok és a nyél famaradványával a jobb alkarcsontok alsó harmadában, annak belső oldalán. Vas harapófogó - a jobb alsó lábszárcsontok felső harmadának külső oldalán. Négyzet alakú vaslemez mindkét oldalán és a peremén famaradványokkal. Ismeretlen rendeltetésü vastárgy - a jobb alsó lábszárcsontok felső harmadának a külső oldalán."'14

$\mathrm{Az}$, hogy a sír egy nagyobb temetőből került elő vitán felül áll. A halott mellé helyezett tárgyak ugyan a feltárt 27 sír ismeretében "gazdagnak" mondható, de nem volt fegyvere, lóval való temetkezésnek pedig az egész temetőrészletben nyoma sincs. Ami viszont figyelmet érdemel az a tény, hogy a fogó, a vaseszközök, illetve az ezüst övveretek egy csomóban kerültek el, ezért feltehetőleg egy egységet alkottak azok szemében, akik a temetés szertartását végezték.

\section{Damjanich János Múzeum}

A Damjanich János Múzeum gyűjteményében a fentebb ismertetett eszközkészleteken túl találunk egy agyag öntőmintát, amely valahonnan a megye területéről került elő. Ennél pontosabb helyhez kötést nem tudunk adni. ${ }^{15}$ Ezen tanulmányban való említését a rajta lévő tárgyak indokolják. Ez a töredék két tárgy öntésére volt alkalmas. Az egyik egy egyenlő szárú bizánci típusú kereszt, a másik egy félhold alakú lapos lunula. Magunk is tisztában vagyunk azzal, hogy e tárgyak más korszakokban is használatban voltak, így például az Árpád-korban. Mi több legutóbb Nevizánszky Gábor és Prohászka Péter azt feltételezték, hogy a: „Gazdag kivitelü, nemesfémböl készült félhold alakú csüngők eredetileg a Kijevi Rusz déli tartományaiban készültek, ezeket később gyatrább kivitelben tömegesen utánozták Közép-Európában, így a Kárpát-medencében is, ahol két helyről öntőminta is elökerült: Deutsch-Altenburgból és Jász-Nagykun-Szolnok megyéből."16 Ennek értelmében e helyen történő említése feltételes.

\section{Összegzés}

Felsorolásunkból kiderül az, hogy egy viszonylag kis területen meglehetősen sok olyan sír látott napvilágot, melyekben valamiféle fémmegmunkáló szerszám vagy szerszám-együttes volt. Dolgozatunk megírásának kezdetekor azt a kérdést tettük fel magunknak, hogy vajon lehetséges-e ezeket a "mestereket" egységesen a társadalom hierarchiájában, vagy esetleg saját közösségükön belül elhelyeznünk, vagy sem?

Kérdésünkre egyértelmú választ nem kaptunk. Úgy tűnik, mintha különböző státuszú emberek alkotnának valamiféle, általunk ismeretlen elvek mentén szerveződő csoportokat. Az egyetlen közös elem náluk a veretes öv megléte. Amennyiben elfogadjuk Fancsalszky Gábor azon megállapítását, miszerint: "A veretes öv nem minden szabad, fegyveres, lovas férfi jelzöje, hanem a helyi vezetök társadalmi pozíciójára utalhat", ${ }^{17}$ akkor minden szerszámmal eltemetett férfi a helyi közösségen belül valamiféle különleges szerepet tölthetett be. Ezen általános megállapításon túl úgy véljük, hogy mégiscsak lehettek közöttük különbségek is.

Vannak olyan férfiak, akiket lovukkal és fegyvereikkel együtt temettek el. Szembetűnő a kunszentmártoni és a kisújszállási mesterek szerszámkészletének nagyfokú hasonlósága mellett a melléjük helyezett fegyverek hasonlósága is. Megkockáztatjuk, hogy ez a két férfi aktív harcosa volt a korai avar hadseregnek is. Az viszont feltűnő, hogy Kisújszálláson több olyan tárgycsoport is előfordult a sírban, amelyek egyébként szokatlanok a korszak fegyveres, lovas sírjaiban. Itt nem csupán a kőeszközökre gondolunk, hanem a különböző állatkarmokra is. Ezek együttesen sugallják azt, hogy a férfi életében nem csupán ötvösmester, harcos katona, hanem valamiféle kultikus szerepet betöltő tagja is lehetett a közösségnek.

Fegyverével és lovával temetik el a rákóczifalvi ötvössír halottját is, de a szablya sírba tétele a korszakon belül időrendileg egy későbbi időpontra utal. Véleményünket erősíteni látszik magának a temetőnek a leletanyaga is. Míg az előző két sír inkább a 7. század első harmadának a végére, utóbbi a század harmadik harmadára keltezhetó.

14 Madaras 2001, 174, és 4. kép 1.

15 Madaras 2001, 177, és 18. kép 1.

16 NeviZÁnsZKY - ProhásZKa 2016, 281.

17 FANCSALSZKY 2007, 121. 
Nincs lovastemetkezés a többi sírban, noha a gátéri közösségben gyakorolták a szokást. Karcag-Berekfürdő esetében a temető feltáratlansága miatt a kérdést nyitva kell hagynunk. Ugyanakkor ezen sír értékelésekor a feltárt sírcsoport viszonylagos szegénysége mellett meg kell említenünk - mint igazi különlegességet - az 1 . sír ténylegesen trepanált koponyáját, amely a maga korában igazi unikumnak számított.

Végezetül meg kell jegyeznünk még a következőket is. Legjobb ismereteink szerint ott, ahol nagy sírszámú temetőből került elő ötvössír, sajnos nem nagyon találunk olyan tárgyat, amelyet az ismert verőtöveken trébeltek volna. Így azután azt a kört sem tudjuk meghatározni, melyhez a késztermék, lett légyen ez bármi, eljuthatott.

\title{
Appendix
}

Sajnos a terjedelmi korlátok nem tették lehetővé, hogy a sírokból előkerült tárgyak rajzos, vagy fényképes tábláit mellékletként közöljük. Erre azonban nincs is szükség, hiszen Rácz Zsófia német nyelvű könyvében, vagy a hivatkozott eredeti közleményekben mindenki megtalálhatja azokat. Kivételt csupán a kisújszállási leletekkel tettünk. Noha ezek is megtalálhatók a fenn említett német nyelvű könyvben, mégis úgy gondoljuk, hogy a Kozma Károly által készített szép színes fotók talán ebben az ünnepi kötetben is szépen fognak mutatni.

A 70. születésnapod alkalmából minden jót és még hosszú munkás éveket kíván Neked: Barátod a Madár.

\section{Goldsmiths and smiths in the heartland of the Hungarian Plain}

\author{
LÁSZLÓ MADARAS
}

The list of relevant burials indicates that several burials containing one or more tools or tool sets used in metalworking came to light in a relatively small area. When starting work on this study, one of my main questions was whether or not these craftsmen occupied a specific position in the period's hierarchy or in their own community.

There is no conclusive answer to this question. It would appear that individuals with differing status formed groups organised according to principles unknown to us. The single shared element was the mount-decorated belt. If we accept Gábor Fancsalszky's contention, that "mount-decorated belts were not indicators of every free, weapon-bearing man, but rather reflected the social position of local leaders", it would imply that men buried with tools had played some special role within their local communities.

Nevertheless, it would appear that beyond this broad generalisation, there were some differences between them. Some men were buried with their horse and weapons. There is a striking resemblance between the tools sets of the craftsmen interred at Kunszentmárton and Kisújszállás, and between the weapons deposited in their burials. It would appear that these two men were active warriors in the early Avar army. It is noteworthy that the Kisújszálás burial contained several objects such as the stone tools and the animal claws that were not customarily deposited in the period's graves containing horse burials and weapons, suggesting that this man was not only a goldsmith, but also a warrior and that he had also played a role in the community's cult life.

The goldsmith buried at Rákoczifalva was interred with his weapon and horse; his weapon, a sabre, indicates a later date within the Avar period, which is also underpinned by the other finds from the cemetery. While the two above-described burials can be assigned to the close of the first third of the seventh century, this burial rather dates to the century's final third.

There are no horse burials in the other graves, although the custom itself was practiced by the Gátér community. This issue remains open in the case of the Karcag-Berekfürdö cemetery because the site has not been fully excavated. The burials of the excavated grave group were rather modestly furnished. At the same time, it must be noted that the man interred in Grave 1 had a trepanated skull, reflecting a practice that was quite rare in the period.

Finally, it must also be noted that to the best of my knowledge, the cemeteries containing a goldsmith's burial rarely yielded metalwork which had been crafted using the known dies, and thus it is difficult to identify the individuals or groups for whom the products, whatever they were, had been made. 

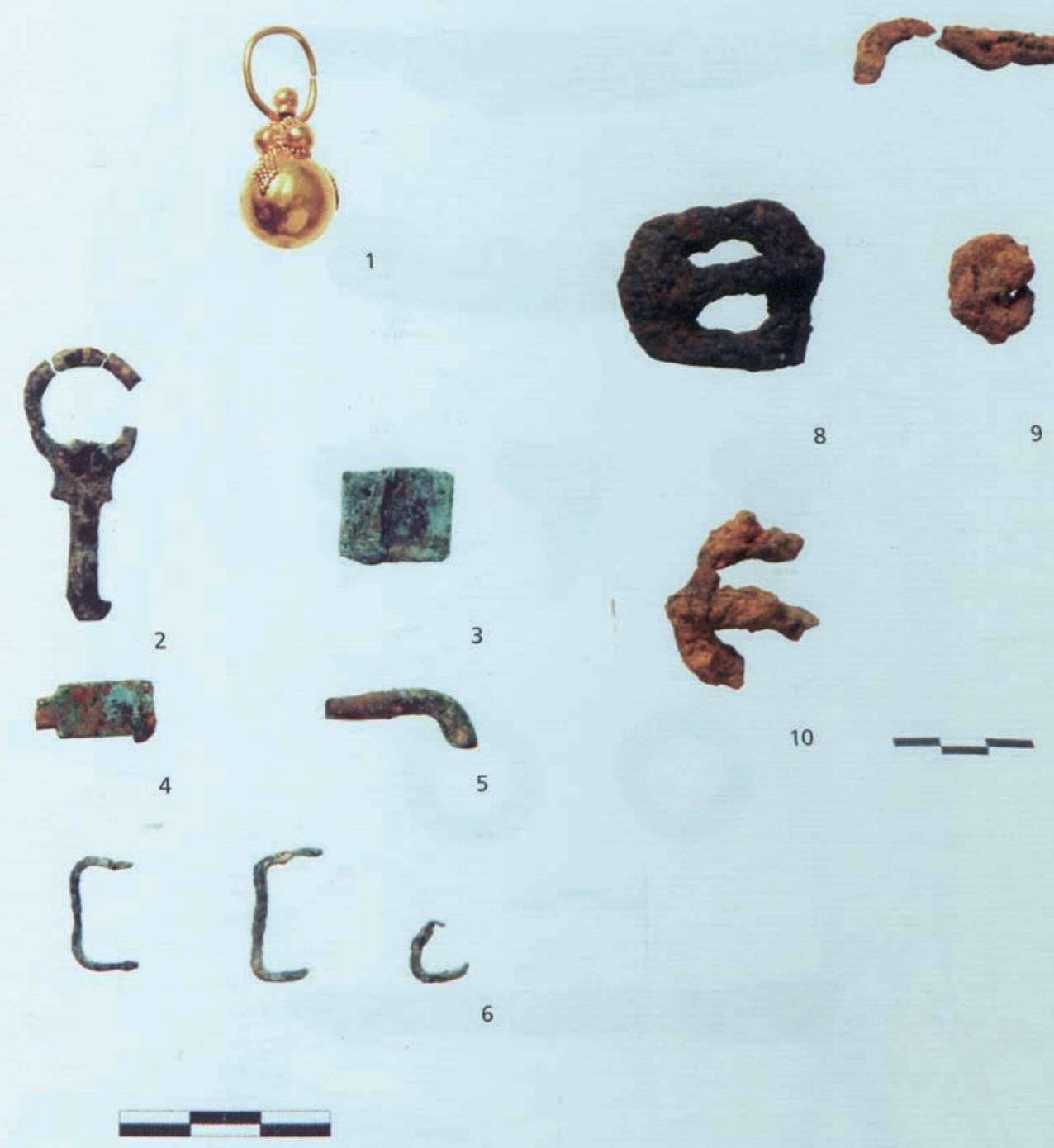

9 

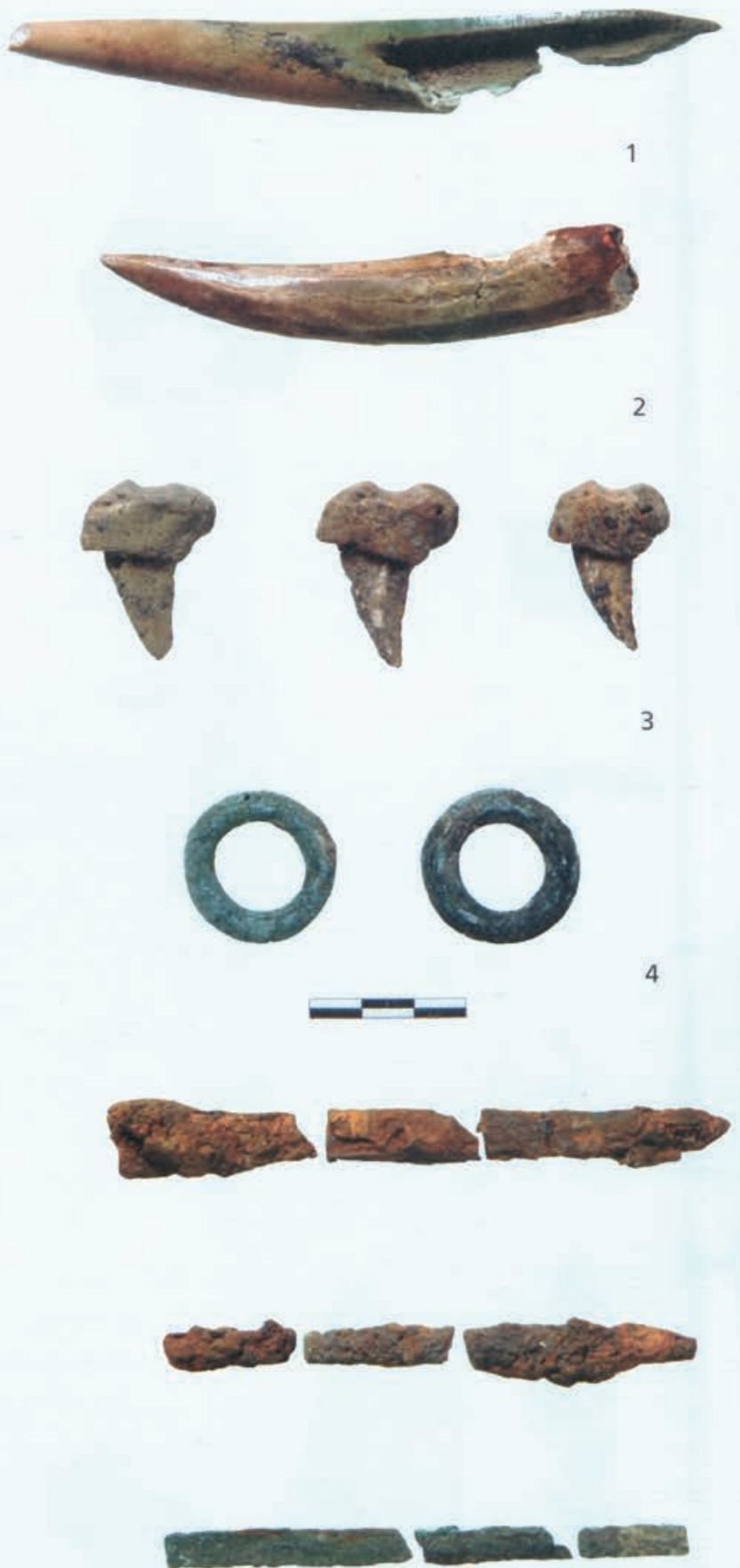


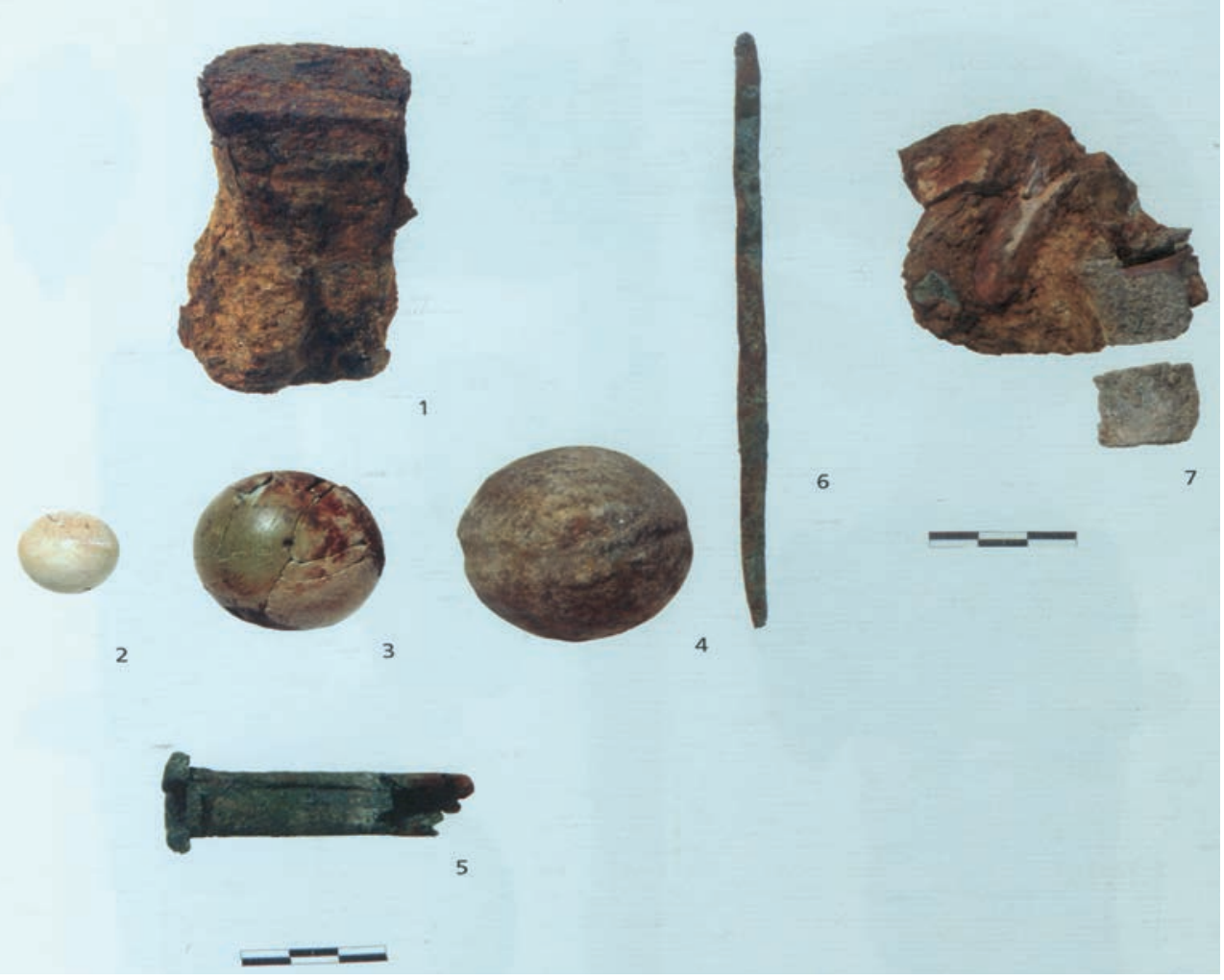

3. ábra. Kisújszállás-Nagykert

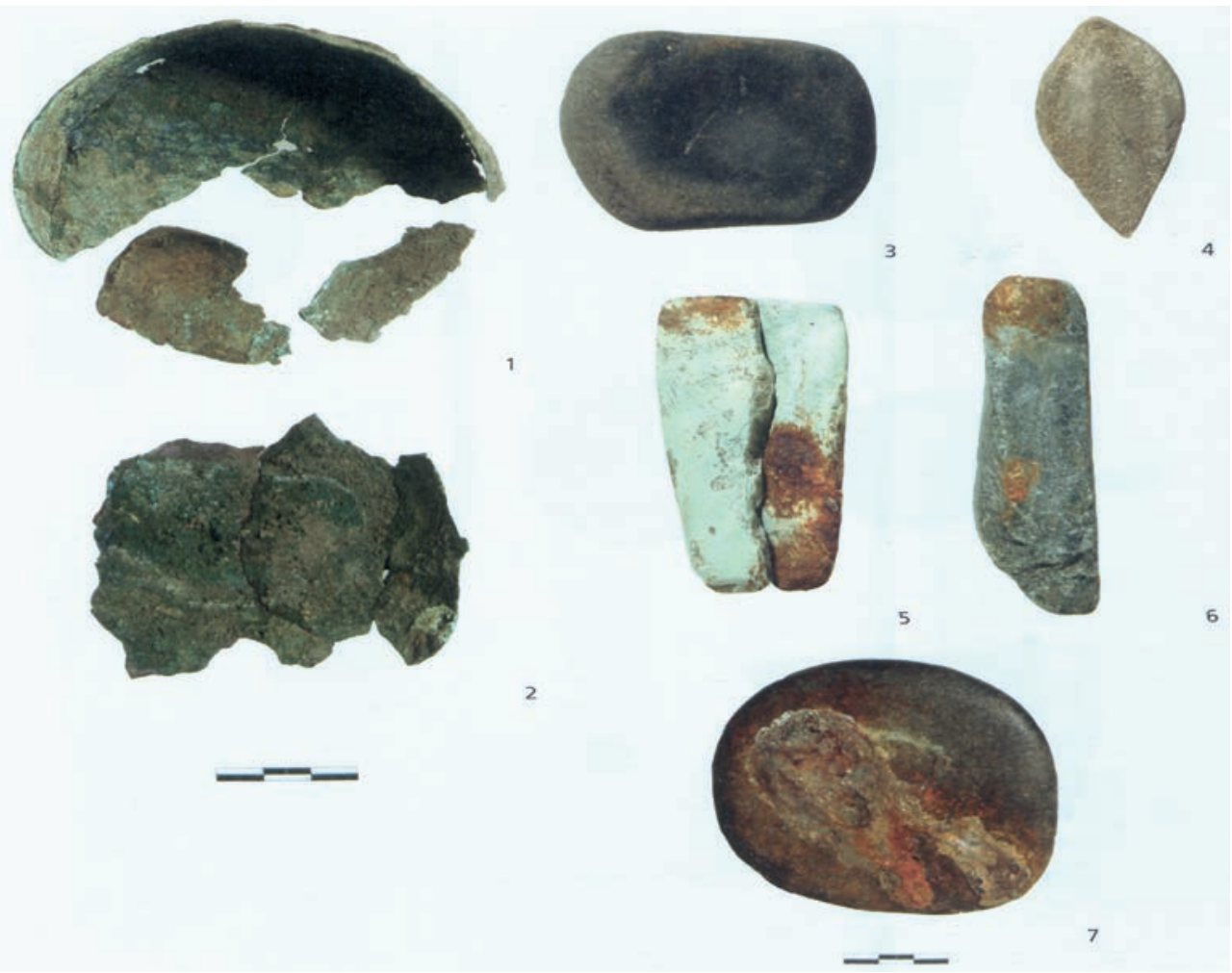

4. ábra. Kisújszállás-Nagykert 


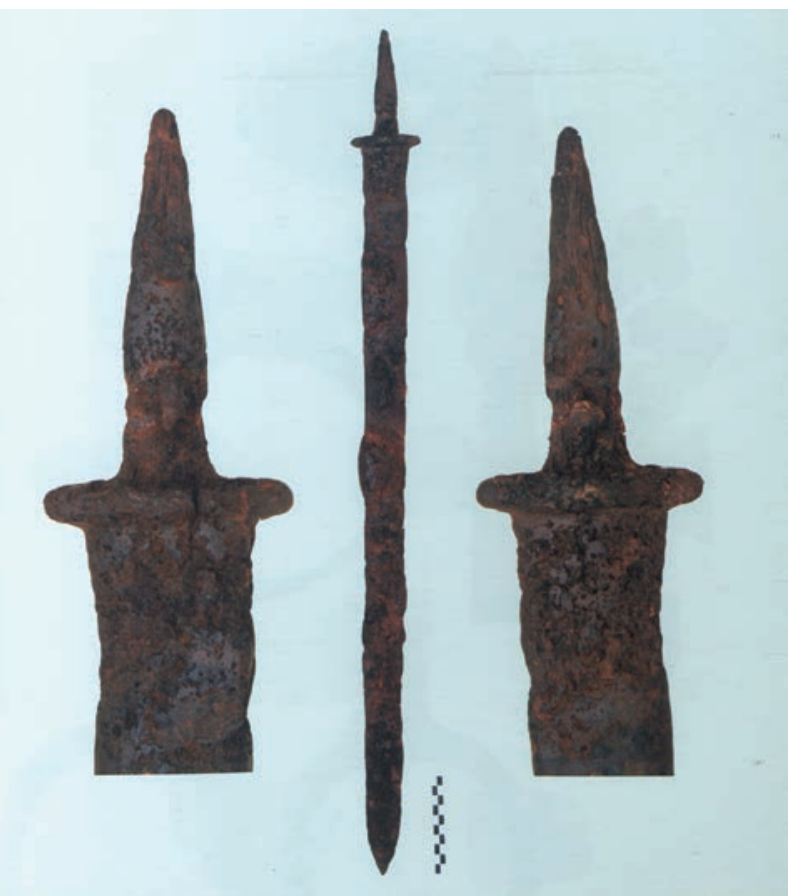

5. ábra. Kisújszállás-Nagykert

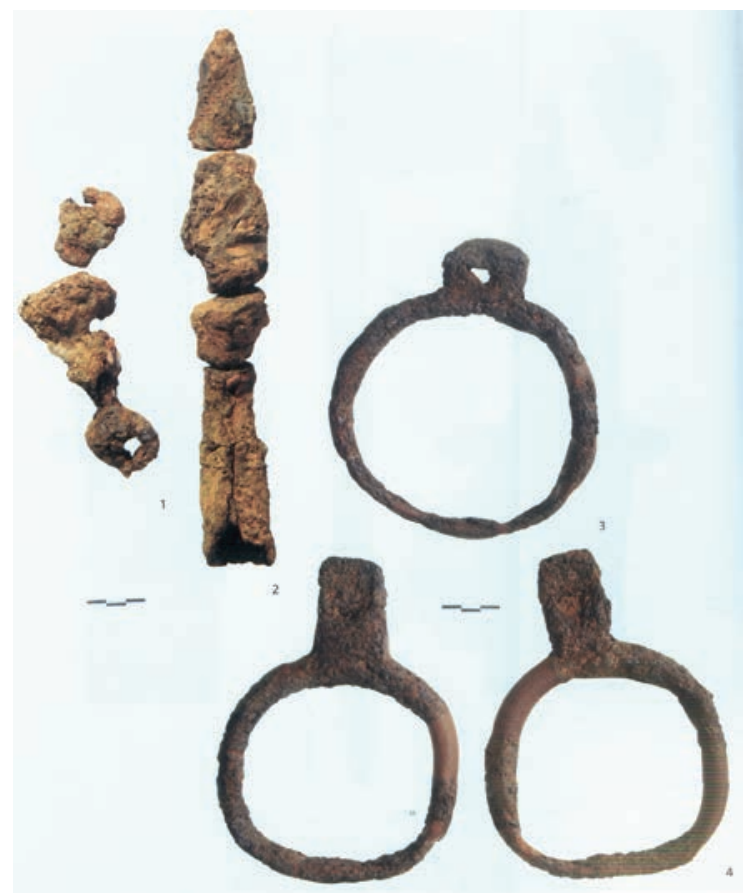

6. ábra. Kisújszállás-Nagykert

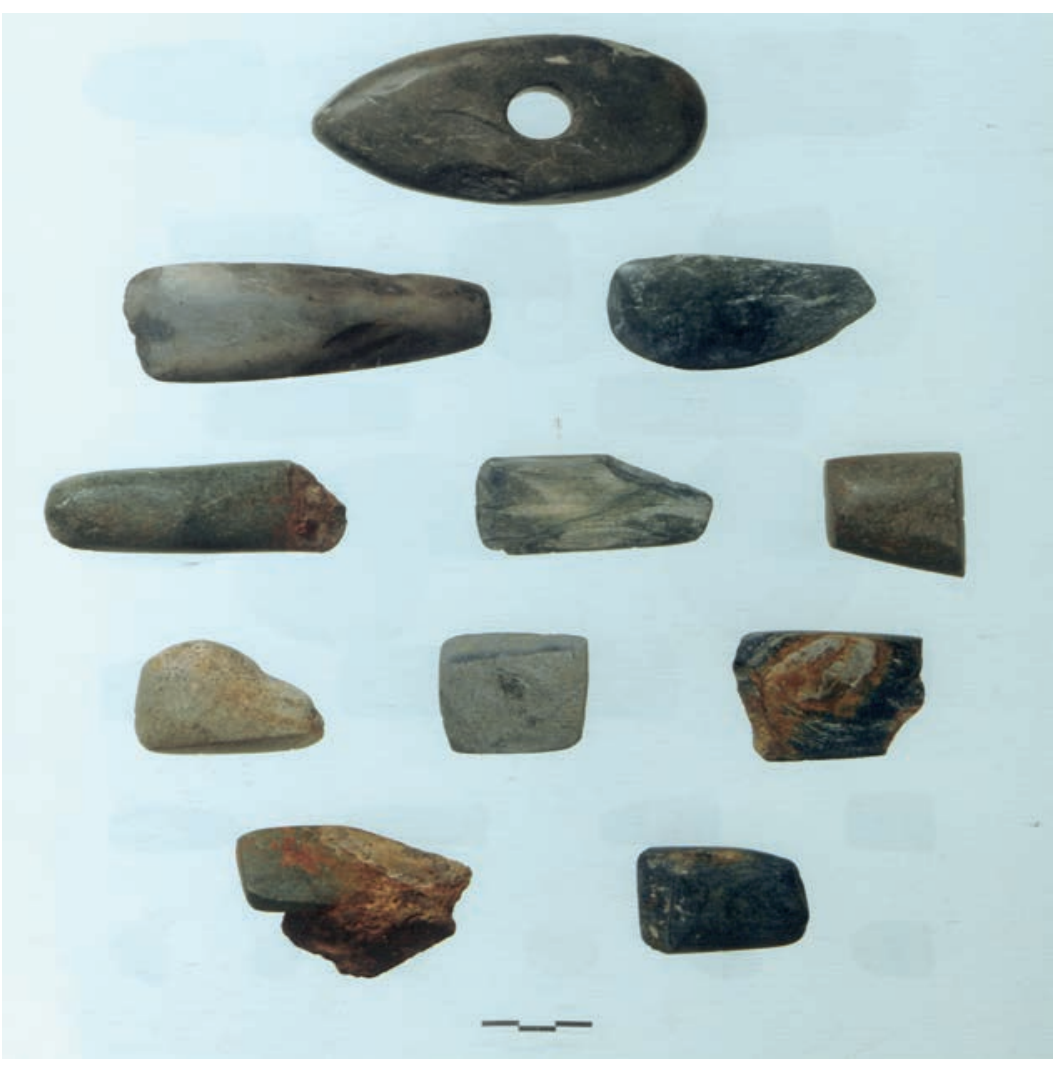

7. ábra. Kisújszállás-Nagykert 

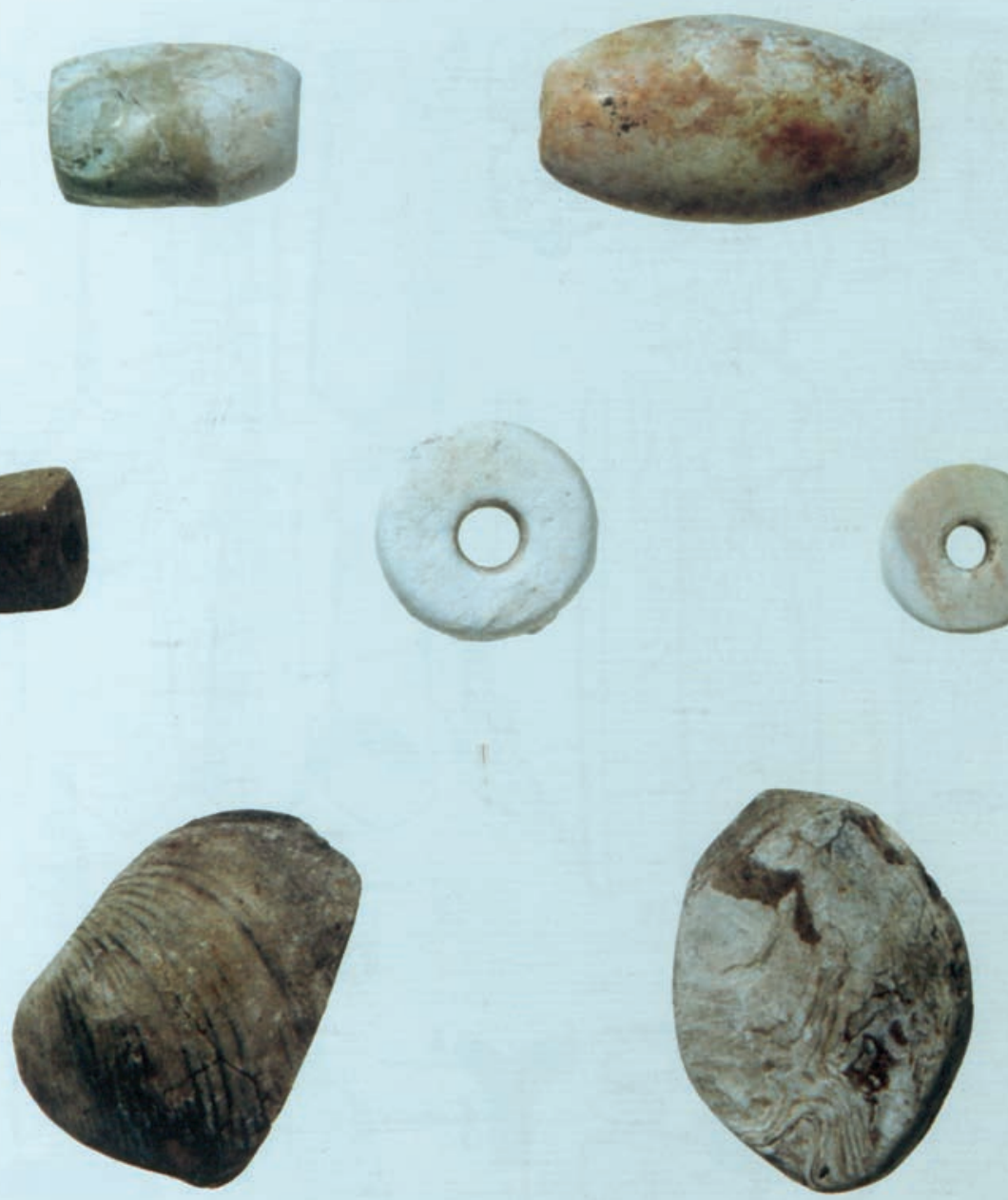

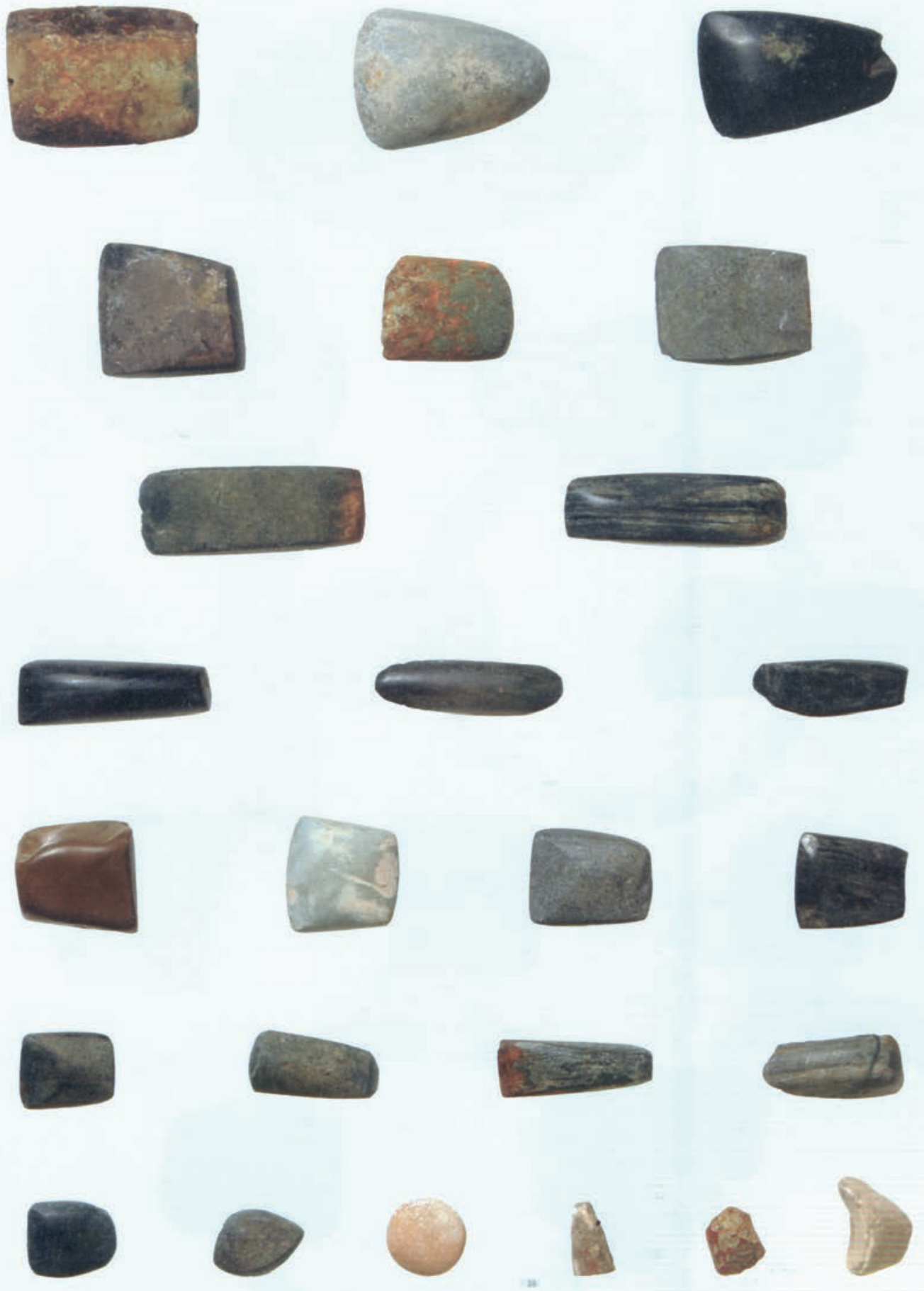

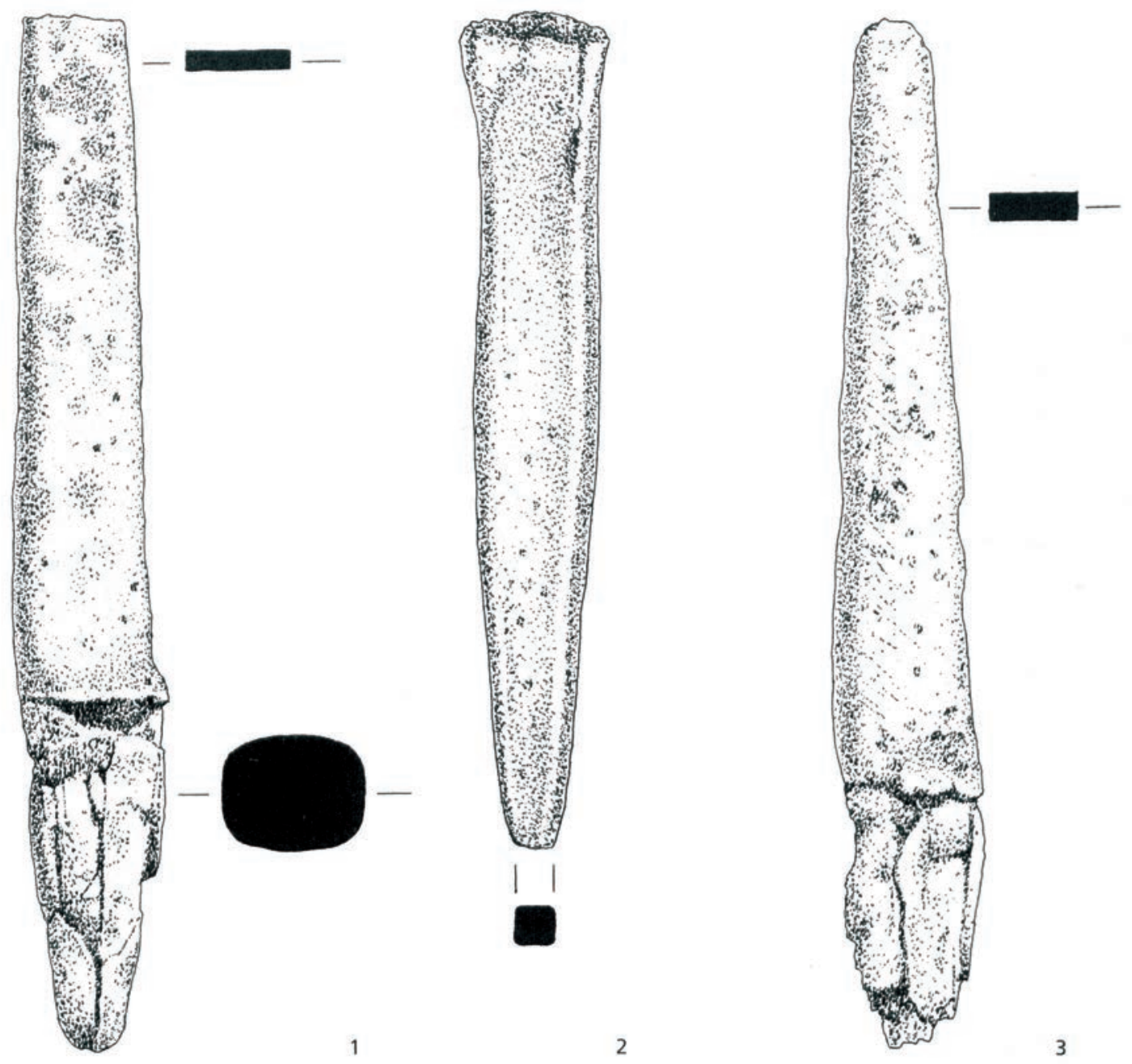

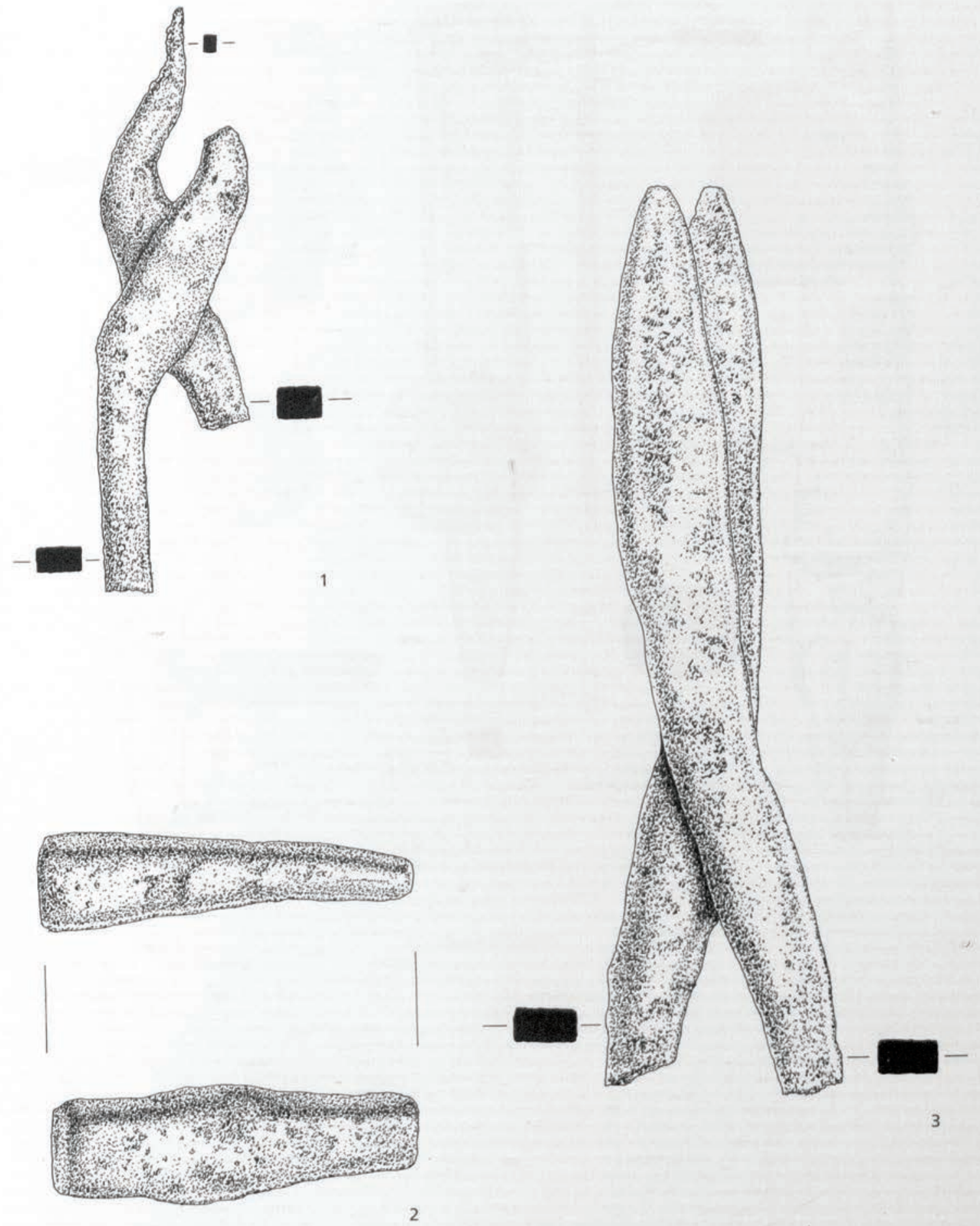

11. ábra. Kisújszállás-Nagykert 


\section{Irodalom}

CSAlLâny 1933 Dr. Csallány Dezső: A kunszentmártoni avarkori ötvössír (Goldschmiedergrab aus der Awarenzeit von Kunszentmárton). Szentes, 1933.

FAnCSALSZKY 2007 Fancsalszky Gábor: Állat- és emberábrázolások a késő avar kori öntött bronz övvereteken (Tier- und Menschendarstellungen auf den Spätawarenzeitlichen gegossenen bronzenen Gürtelbeschlägen). Opitz Archaeologica l. Budapest, 2007.

KADA 1905 Kada Elek: Gátéri (kun-kisszállási) temető a régibb középkorból I. Archaeologiai Értesítő XXV. 360-384.

KIss 2001 Kiss, Attila: Das awarenzeitliche Gräberfeld in Kölked-Feketekapu B. Monumenta Avarorum Archaeologica Vol. 6. Budapest, 2001.

MADARAS 2001 Madaras László: VII-VIII. századi avar temetőrészlet Berekfürdőről (Das Awarische Friedhofsteil aus den 7.-8. Jahrhunderten in Berekfürdő). TISICUM A Jász-Nagykun-Szolnok Megyei Múzeumok Évkönyve XII. 173-196.

SelmECZI - MadARAS 1979-1980 Selmeczi László - Madaras László: Avarkori és X-XII. századi magyar köznépi sírok Rákóczifalván (Avar and X-XIIth century Hungarian Common graves at Rákóczifalva). Szolnok Megyei Múzeumok Évkönyve IV. 141-172.

NevizÁnsZky - Prohászka 2016 Nevizánszky Gábor - Prohászka Péter: Közép- és kora újkori sírok naszvadi Jánoska-partról. (Mittelalterliche und frühneuzeitliche Gräber aus dem Naszvader Jánoska-part). TISICUM A Jász-Nagykun-Szolnok Megyei Múzeumok Évkönyve XXV. 279-285.

RÁcz 2009 Rácz Zsófia: Avar kori ötvös-és kovácsszerszámok (Schmidt and goldsmith tools from the Avar period). In: Nagy Zoltán - Szulovszky János (szerk.): A vasmüvesség évezredei a Kárpát-medencében. Szombathely, 2009. 67-96.

RÁcz 2012 Rácz Zsófia: Emberalakos kistárgyak az avar korból (Anthropomorphe Kleinfunde aus der Awarenzeit). In: Vida Tivadar (szerk.): Thesaurus Avarorum. Régészeti tanulmányok Garam Éva tiszteletére. Budapest, 2012. 409-436.

RÁcz 2014 Rácz, Zsófia: Die Goldschmiedegräber der Awarenzeit. Mainz, 2014.

Somogy 1982 Somogyi, Péter: A Kárpát-medencei sarlós temetkezési szokás eredete (Urspung des Bestattungsbrauches mit Sichel im Karpatenbecken). Archaeologiai Értesítő 109. 191-200. 
